\title{
Non-Parametric approach to measuring the efficiency of banking sectors crediting agribusiness in ASEAN countries
}

\author{
Linh Trinh Doan Tuan ${ }^{1, *}$ \\ ${ }^{1}$ Military Commercial Joint Stock Bank, University of Economics and Law, Vietnam National \\ University, Tran Quoc Thao St, Ward 9, Dist 3, Ho Chi Minh, Vietnam
}

\begin{abstract}
This paper explores the efficiency of banks in 9 ASEAN countries including Brunei, Cambodia, Indonesia, Laos, Malaysia, Philippines, Singapore, Thailand and Vietnam in the period of $2013-2017$ by using a non-participation approach. Input-oriented DEA method, with the inputs being Equity; Deposits; Loans and Operating expenses with one output are the Total operating income. The results show that the average overall efficiency of ASEAN banks in the study period is $59.2 \%$, with this result, if the output is constant, the banks can save up to $40.8 \%$ of the first. into the business process. Among ASEAN countries in the research period, banks in Indonesia, Cambodia and Thailand are among the most effective with the efficiency of 0.7460 .745 and 0.605 . Banks in Vietnam, Malaysia and Brunei had the lowest average efficiency during the study period with average efficiency of $0.514,0.538$ and 0.544 .
\end{abstract}

\section{Introduction}

Association of Southeast Asian Nations (ASEAN) is an intergovernmental organization established on 8/8/1967 in Bangkok, Thailand with the main objective of strengthening cooperation. Political, security, economic and cultural-social relations between member countries, facilitating deeper integration with the region and the world. ASEAN includes 10 countries in Southeast Asia: Indonesia, Malaysia, Philippines, Singapore, Thailand, Brunei, Vietnam, Laos, Myanmar and Cambodia.

Integration in the financial and banking sector has always been identified as one of ASEAN's important strategies to pursue the goal of establishing a highly regionally connected financial market. Commercial banks, financial intermediaries play an important role in the financial system of any country; the operation of commercial banks greatly affects the health of the economy. After the Asian financial crisis in 1997 and the global financial crisis in 2008, most of the banking systems in ASEAN countries have made the recovery process through restructuring and financial reform. . Some banks in the respective countries have been taken over by the government, while others have received government support, some commercial banks have been acquired by other financial institutions, others

\footnotetext{
*Corresponding author: banker@asia.com
} 
being forced to merge with other banks and organizations with greater capacity and potential.

According to [1], past crises have further clarified the role of the banking market to promote economic progress and national development. The failure of a financial authority to monitor and control risks related to financial innovation creates instability in the financial system, inability to use foreign capital and short-term capital flows. volatile into weak and inefficient financial systems, is the immediate catalyst of the crisis. In the current competitive and integrated environment, the ASEAN countries' banking sectors must not only maintain operational efficiency and must improve its competitiveness with nonbanking financial institutions, and compete with other banks. Foreign banks are entering the ASEAN market day by day to gain market share. Therefore, the measuring the performance of commercial banks in ASEAN is very necessary and valuable, helping bank managers and financial policy makers in ASEAN. directions and strategies for sustainable development for the system of commercial banks each country in ASEAN.

Stemming from the practical needs mentioned above, in past there have been many studies on the effectiveness of commercial banks in ASEAN countries such as [2] studied the effectiveness of banks in Thailand, Indonesia, Malaysia, Philippines, or research by [3] explores the efficiency of banks in 5 countries including Vietnam, Thailand, Malaysia, Philippines, Indonesia in 1998-2004; [4] Analyze the efficiency of banks in 4 countries Indonesia, Malaysia, Philippines Thailand during 2000-2010, [5] analyzed the effectiveness of 15 commercial banks with the largest total assets of 5 SEAN countries including Indonesia, Malaysia, Thailand, Singapore, Philippines in the period of $2005-2016$.

Thus, although the issue of measuring the performance of commercial banks in ASEAN has been concerned for research.

However, the fundamental limitation of the study is that the research context is old and the scope of the study applies to a small number of commercial banks of a few countries out of 10 ASEAN countries so it is not countered fully reflect the operation as well as the efficiency of the banks in ASEAN.

Therefore, the objective of this paper will provide an overall picture of the operation of commercial banks in ASEAN through measuring the performance of 130 banks in 9 ASEAN countries including: Brunei, Cambodia, Indonesia, Laos, Malaysia, Philippines, Singapore, Thailand and Vietnam, the results will show the effectiveness of each bank and the overall efficiency of the banks in each country in ASEAN.

\section{Literature Review}

According to [6], by the end of 2009, there were about 204 studies in 63 countries on banking performance in the world. In total of 204 studies on the Bank's efficiency, 120 studies used non-parametric method, 84 studies used parametric method. In the nonparametric method, data envelopment analysis (DEA) accounted for 109 of 120 studies. Stochastic Frontier Analysis (SFA) methods accounted for 67 of the 84 parametric approach studies.

Thus, from the study of [6] shows that, to measure the performance of banks previous studies use two different approaches: parametric and non-parametric methods. In parametric method, the use of the method of stochastic frontier analysis (SFA) with 67 out of 84 and about $80 \%$ of the studies, in the non-parametric approach, the method of data envelopment analysis ( DEA) is used in almost all studies, accounting for 109 over 120 and accounting for $91 \%$ of the past studies.

In recent years, there have been many banking efficiency studies in many countries and territories also using two main methods, DEA and SFA. Non-parametric approaches to data envelopment analysis (DEA) include: 
[7] with DEA method which analyzed the performance of 26 banks operating in the South. Africa.

[3] use data envelopment method (DEA) to measure technical efficiency of banks in Vietnam, Thailand, Malaysia, Philippines, Indonesia in 1998. - 2004.

[8] use the DEA approach to estimate the effectiveness of the Indian banking system.

[4] uses DEA to estimate the effectiveness of commercial banks in 4 ASEAN countries.

[9] uses the DEA approach to estimate the effectiveness of the system of 217 commercial banks of 10 MENA countries (Middle East and North Africa).

[10] study the effectiveness and competitiveness of the Mexican commercial banking system by using a non-parametric DEA approach.

Parametric approaches by stochastic frontier analysis (SFA) include:

$[11,12]$. used the method (SFA) to measure the efficiency. As a result, commercial banks operate in Vietnam.

Thus, the Literature Review shows that the DEA method is most commonly used to measure the performance of banks. This paper also applies DEA method to measure the performance of commercial banks in ASEAN countries in the period of 2013 - 2017.

\section{Methodology}

\subsection{Input-oriented DEA method}

The DEA method was proposed by [7] (CCR), based on [13, 14] idea of estimating technical efficiency with production boundaries. The main idea of a classic DEA is to determine the production boundary, on which the decision points for the DMUs are considered to be effective, the non-frontier DMUs will be compared with the equivalent DMUs on the boundary to estimate. efficiency points. [15] made the assumption that the production efficiency varies with the scale (VRS) of the BCC model.

In the DEA method, there are two approaches: output orientation (maximizing output) and input orientation (input minimization). In the output-oriented approach, the same inputs are the same, which enterprise has the highest output will be most effective. which industry has the lowest input will be most effective and vice versa. Both approaches produce the same results, depending on the conditions and views that can choose the appropriate approach. This paper will approach the input-oriented DEA method.

To describe this problem, let's assume a hypothetical example with 2 inputs $x 1, x 2$ and one output y (according to Figure 1). Enterprises A, B, C and D on the SS efficiency limit line 'are the ones that are effective. The level of technical inefficiency is reflected by the distance from $\mathrm{B}$ to $\mathrm{P}$. The ratio $\mathrm{TE}=\mathrm{OB} / \mathrm{OP}$ represents the technical efficiency of enterprise $\mathrm{P}$, which means that input $\mathrm{P}$ can be reduced but Do not affect the output. By definition, these levels of effectiveness range from 0 to 1 . 


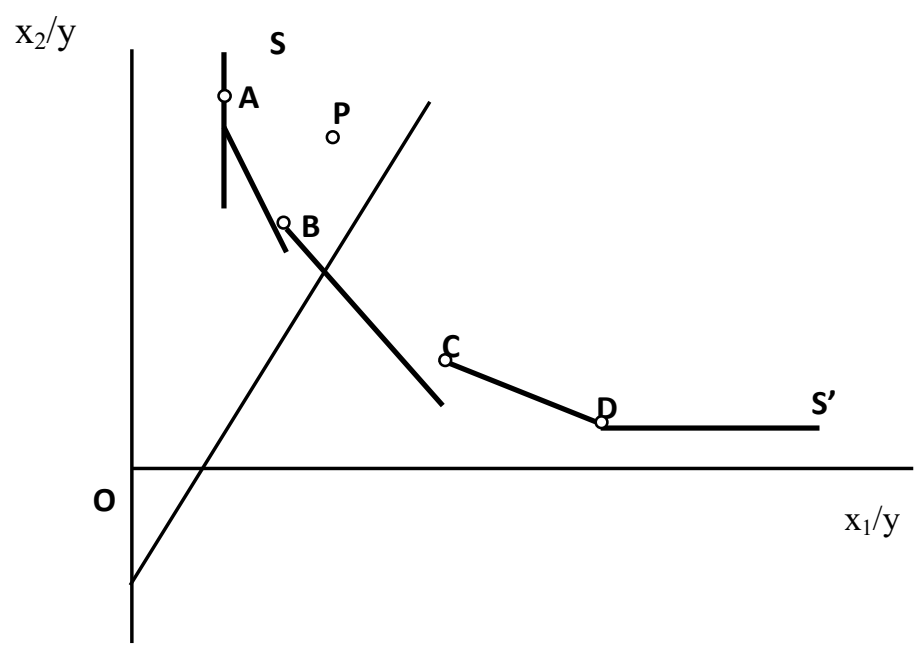

Fig. 1. Input-oriented DEA model [16].

Input-oriented DEA model with effect varies of scale (DEAVRS)

$$
\begin{gathered}
\min _{\theta, \lambda}(\theta), \\
-y_{i}+Y \lambda \geq 0, \\
\theta x_{i}-X \lambda \geq 0, \\
N 1 \lambda=1 \\
\lambda \geq 0
\end{gathered}
$$

In which, $\theta$ - scalar quantity, showing the efficiency level of the Bank

$\lambda$ - Vector constant $\mathrm{Nx} 1$;

$\mathrm{N} 1$ - Unit vector Nx1.

[16] and [17] classified technical efficiency into two components: pure technical efficiency and scale effectiveness. The DEACRS score is called the general technical performance (CRS TE). On the other hand, DEAVRS exhibits purely technical efficiency in reverse-engineering situations (or VRS TE). If a DMU is completely effective (100\%) in both DEACRS and DEAVRS, it operates at its largest scale. If a DMU has a full DEAVRS score but low DEACRS efficiency, then it works locally but not globally effective due to the size of the DMU. This is shown as follows:

Technical efficiency (TE) = Pure efficiency (PE) x Scale effect (SE) 


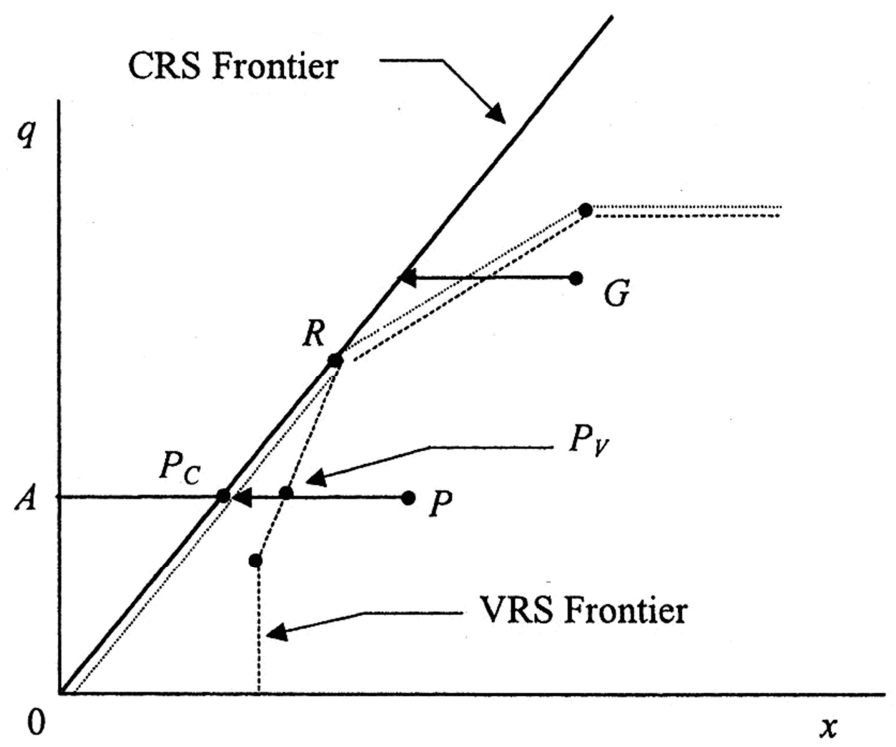

Fig. 2. The Effect varies of scale input oriented [8].

\subsection{Malmquist index}

Malmquist index is the index reflecting the change of the measures of technical efficiency, technological progress, pure efficiency, scale efficiency and total factor productivity. Malquist index greater than 1 indicates productivity increase and vice versa, Malquist index less than 1 will indicate decreased productivity.

Output can still be increased by optimizing the use of inputs (labor and capital) by combining the best use of the inputs combined with improved management and technological innovation., apply scientific and technical advances in activities, improve labor quality (collectively referred to as general factors). Combining the above factors will create new value including: the value of the contribution of each input element plus the new value (added value) created by the invisible factor. This value is expressed through total factor productivity (TFP).

\subsection{Input and output selection}

There are two main approaches to assessing the effectiveness of banks: the intermediate approach and the production approach. The different origins of these two approaches are from the operational function of commercial banks, previously commercial banks were considered as financial intermediaries, however, there is another view that banks trade as well as a manufacturing business, ie using inputs such as capital, labor ... to produce products and services. In the bank's efficiency study, the main difference between these two points is that customer deposits are inputs or outputs of the bank, according to the intermediary approach, deposits are an input then the production approach assumes that deposits are also a product of a bank's service, so it is an output factor. [18, 19] stated that there is no perfect approach to determining bank inputs and outputs because no approach can fully reflect all the bank's activities and roles. goods as an organization providing financial services. According to him, the intermediary approach is most suitable, considering banks as financial intermediaries between the savings and investment sector 
and he thinks that the intermediary method can assess the entire financial institution while Production methods are more suitable for comparing effectiveness between branches in a bank. In this study, the author uses an intermediary approach and deposit is one of the input variables of the research model.

In previous studies, [2] used input variables including: employee salary cost; Cost of fixed assets such as land, factory and equipment costs; Deposit interest and output variables are: Commercial, industrial and other loans; Deposits and savings; Securities and investments.

[2] uses 3 inputs: Price of funds; Price of fixed assets; Price of employees and 4 outputs Total deposits; Total loans; Total investments; Non-interest income.

[20] uses three inputs the number of employees; Fixed assets; Total deposits and 3 outputs are Total loans; Income on other assets; Income from other activities. [21,22] use 4 inputs: Personnel cost; Other administrative expenses; Interest paid; Other expenses besides interests and 2 outputs: Total loans and Income from other assets.

[23] uses 3 inputs as Total net fixed assets (Total assets minus loans and investments); Expenses for employees; Total capital mobilized from customers and 2 outputs are Interest income and interest equivalent; Non-interest income and the like. [7] have 2 inputs: Deposits and total expenditures for employees, 1 output is Total loan.

[3] use 3 inputs: Fixed assets (Fixedassets); Deposits and Personnel costs, along with two output net loans and earning assets. [16] used 3 inputs: Number of employees; Equity; deposits and outputs are net loans.

[19] use 2 inputs Interest expense; Operating expenses and 2 outputs are Interest income and interest equivalent; Income from fees and the like.

[9] uses 4 inputs Total assets; Interest expenses; Equity; operating costs and 3 outputs are undistributed profits; Income before taxes; EPS uses 4 inputs at the same time; Interest expenses; Operating expenses; The risk provision expense and the output are pre-tax income.

[4] used 3 inputs are Salary cost (Total salary / total staff); Equipment expenses (other property costs); Interest on deposits (interest amount / 1USD deposit) and 2 outputs Total loan; Total deposit and securities investment.

This paper will inherit some of the input and output variables of the previous studies and add new variables to the gaps of previous studies, so in the model of banks' performance.

New in the model of banks' performance research in this paper is the author added the independent variable (input), the Bank's borrowed capital (Loans) that the previous studies have not used. Among current inputs of banks other than equity, deposits of customers, loans (loans from central banks, loans from other banks, issuance of bonds and debt certificates ...) of banks accounted for a relatively large proportion and played an important role in the operation of banks.

\section{Data}

Data sources on the banking system of ASEAN countries in the period of 2013-2017 are taken from the annual reports of banks and official figures of international financial institutions such as IMF, WB, ADB ... Data from Annual reports of banks in ASEAN countries in US dollar (USD). Banks in the annual report that do not have USD units are allowed to convert from local currencies to USD in the following ways: (1) Transfer at the USD exchange rate stated in the banks' annual reports there; (2) Transfer at the cross exchange rate of the central bank of Vietnam at the reporting time. 
Table 1. Summary of Descriptive Statistics.

\begin{tabular}{|l|c|c|c|c|c|}
\hline \multicolumn{1}{|c|}{ Variables } & Obs & Mean & Std.Dev & Min & Max \\
\hline $\begin{array}{l}\text { Y - Total operating } \\
\text { income }\end{array}$ & 650 & $1,000,675$ & $1,333,351$ & 14 & $7,629,859$ \\
\hline X1 - Equity & 650 & $3,418,615$ & $4,598,689$ & 483 & $37,289,492$ \\
\hline X2 - Deposits & 650 & $23,713,472$ & $3.13 \mathrm{e}+07$ & 1,406 & $279,760,291$ \\
\hline X3 - Loans & 650 & $3,935,266$ & $5,829,161$ & 1 & $56,256,951$ \\
\hline $\begin{array}{l}\text { X4 - Operating } \\
\text { expenses }\end{array}$ & 650 & 459,737 & $1,048,457$ & 400 & $3,897,269$ \\
\hline
\end{tabular}

Table 2. Bank inputs and outputs in ASEAN 2013-2017.

\begin{tabular}{|c|c|c|c|c|c|c|}
\hline & \multirow{2}{*}{$\frac{\text { Output }}{\mathrm{Y}}$} & \multicolumn{4}{|c|}{ Input } \\
\hline & & & $\mathrm{X} 1$ & $\mathrm{X} 2$ & $\mathrm{X} 3$ & $\mathrm{X} 4$ \\
\hline & Mean & 643,167 & $1,796,735$ & $13,509,382$ & $2,025,571$ & 525,792 \\
\hline 2013 & $\operatorname{Max}$ & $7,185,009$ & $27,552,865$ & $235,313,683$ & $38,835,430$ & $1,719,557$ \\
\hline & Min & 16 & 483 & 1,087 & 2 & 400 \\
\hline & Mean & 693,369 & $1,905,605$ & $13,407,220$ & $1,989,784$ & 307,276 \\
\hline 2014 & Max & $7,629,859$ & $31,894,999$ & $251,610,018$ & $47,491,864$ & $3,434,944$ \\
\hline & Min & 205 & 2,666 & 671 & 30 & 471 \\
\hline & Mean & 705,562 & $2,245,766$ & $13,599,582$ & $1,870,721$ & 324,342 \\
\hline 2015 & Max & $6,593,183$ & $34,042,500$ & $241,997,490$ & $51,957,035$ & $3,704,036$ \\
\hline & Min & 52 & 2,728 & & 1 & 475 \\
\hline & Mean & 745,665 & $2,182,313$ & $14,398,913$ & $1,894,340$ & 355,580 \\
\hline 2016 & Max & $6,379,635$ & $35,083,882$ & $295,522,129$ & $44,484,151$ & $3,713,797$ \\
\hline & Min & 14 & 3,575 & 658 & 1 & 432 \\
\hline & Mean & 815,505 & $2,388,719$ & $15,857,100$ & $2,173,022$ & 375,368 \\
\hline 2017 & Max & $7,283,888$ & $37,289,492$ & $279,760,291$ & $56,256,951$ & $3,897,269$ \\
\hline & Min & 143 & 6,491 & 2,742 & 3 & 626 \\
\hline & ean & 720,654 & $2,103,828$ & $14,154,439$ & $1,990,688$ & 377,672 \\
\hline & $a x$ & $7,629,859$ & $37,289,492$ & $295,522,129$ & $56,256,951$ & $22,380,778$ \\
\hline & in & 14 & 483 & 658 & 1 & 400 \\
\hline
\end{tabular}

The variables of the model include 4 input variables:

Equity (Input1-EQT). Data taken from the equity of the commercial bank include: Capital of the bank (Charter capital, treasury shares), Funds of the bank and undistributed profits in the balance sheet of banks. Deposits (Input2 - DEP). Taken from customers' deposit in the balance sheet banks. Loans (deposits and borrowings from other banks, central bank loans, issuance of valuable papers, debt securities, other borrowings. Input3 BOR). Data are taken from: Government and central bank debts; deposits and borrowings from other banks; issue valuable papers, other liabilities ... in the section liabilities on the bank's balance sheet. Operating expenses (Input4 - OPE), data are taken from Operating expenses in the bank's income statement.

Output variable: Total operating income (Output - TOI). Figures taken from the bank's income statement include: Net interest income; Net profit / loss from service activities; Net gain / loss from foreign currency trading; Net gain / loss from securities trading; Net gain / loss from other activities.

Input and output variables are described in details in tables 1, 2 and 3 below in a currency unit of thousands of dollars. 
Table 3. Bank inputs and outputs by countries in ASEAN 2013-2017.

\begin{tabular}{|c|c|c|c|c|c|c|}
\hline & \multirow{2}{*}{$\frac{\text { Output }}{\mathrm{Y}}$} & \multicolumn{4}{|c|}{ Input } \\
\hline & & & $\mathrm{X} 1$ & $\mathrm{X} 2$ & $\mathrm{X} 3$ & $\mathrm{X} 4$ \\
\hline \multirow{3}{*}{ Vietnam } & Mean & 288,849 & 611,364 & $6,455,446$ & $1,427,725$ & 139,245 \\
\hline & Max & $1,896,812$ & $2,813,381$ & $44,460,360$ & $11,318,852$ & 869,478 \\
\hline & Min & 21,321 & 57,465 & 407,982 & 954 & 13,157 \\
\hline \multirow{3}{*}{ Brunei } & Mean & 144,189 & 518,029 & $2,875,561$ & 220,112 & 53,070 \\
\hline & Max & 264,104 & 994,245 & $5,573,019$ & 399,442 & 88,385 \\
\hline & Min & 80,278 & 106,872 & 755,526 & 4,312 & 20,450 \\
\hline \multirow{3}{*}{ Cambodia } & Mean & 67,257 & 165,649 & 746,128 & 123,208 & 26,537 \\
\hline & Max & 494,809 & 740,215 & $3,363,279$ & $1,118,833$ & 189,864 \\
\hline & Min & 1,041 & 26,374 & 658 & 1 & 400 \\
\hline \multirow{3}{*}{ Indonesia } & Mean & 888,771 & $1,779,184$ & $8,566,924$ & 638,784 & 650,249 \\
\hline & Max & $6,582,679$ & $12,151,332$ & $60,158,105$ & $6,036,119$ & $1,719,557$ \\
\hline & Min & 271 & 14,367 & 29,830 & 65 & 4,252 \\
\hline \multirow{3}{*}{ Laos } & Mean & 16,330 & 45,130 & 386,648 & 58,391 & 10,483 \\
\hline & Max & 130,241 & 214,458 & $3,358,547$ & 640,995 & 65,133 \\
\hline & Min & 14 & 483 & 1,406 & 1 & 432 \\
\hline \multirow{3}{*}{ Malaysia } & Mean & 912,826 & $3,340,617$ & $24,554,367$ & $2,739,896$ & 405,395 \\
\hline & $\operatorname{Max}$ & $3,626,350$ & $15,484,308$ & $105,775,250$ & $14,155,905$ & $2,378,075$ \\
\hline & Min & 16,347 & 98,161 & 100,232 & 29,037 & 7,761 \\
\hline \multirow{3}{*}{ Philippines } & Mean & 413,399 & $1,546,391$ & $7,452,284$ & 342,649 & 248,969 \\
\hline & Max & $2,039,018$ & $34,042,520$ & $39,652,065$ & $2,354,984$ & $1,336,307$ \\
\hline & Min & 32,823 & 79,815 & 579,605 & 8,436 & 38,235 \\
\hline \multirow{3}{*}{ Singapore } & Mean & $4,958,955$ & $19,260,502$ & $139,342,216$ & $27,361,889$ & $1,990,051$ \\
\hline & Max & $7,629,859$ & $37,289,492$ & $279,760,291$ & $56,256,951$ & $3,897,269$ \\
\hline & Min & 156,948 & $1,369,071$ & $21,654,245$ & 51,511 & 92,559 \\
\hline \multirow{3}{*}{ Thailand } & Mean & $1,315,502$ & $3,500,667$ & $23,041,675$ & $2,504,739$ & 613,631 \\
\hline & Max & $4,274,496$ & $12,329,850$ & $72,871,671$ & $11,595,984$ & $2,813,049$ \\
\hline & Min & 78,438 & 116,541 & 185,992 & 36,444 & 21,854 \\
\hline \multicolumn{2}{|c|}{ Mean } & $1,000,675$ & $3,418,615$ & $23,713,472$ & $3,935,266$ & 459,737 \\
\hline \multicolumn{2}{|c|}{ Max } & $7,629,859$ & $37,289,492$ & $279,760,291$ & $56,256,951$ & $3,897,269$ \\
\hline \multicolumn{2}{|c|}{ Min } & 14 & 483 & 1,406 & 1 & 400 \\
\hline
\end{tabular}

\section{Results and discussion}

The estimation results from the model show that the average overall efficiency of ASEAN commercial banks in the study period is $59.2 \%$, this result shows that, with constant output, banks can save as much as possible. $40.8 \% \%$ input during business operation. Thus, the efficiency of ASEAN commercial banks in the period of 2013 - 2017 is relatively low. This may be due to the existing many unsolved ASEAN commercial banks system after the crisis period of 2008-2012, which still had no significant recovery and development [24].

The research results are presented in Table 4, this results shows the average efficiency over the years of the banks in each ASEAN country as follows: Vietnamese banks in 2013 achieved an average of 0.345 after that increased sharply in 2014 to 0.641 and decreased to 0.530 in 2015, in 2016, 2017 remained at only 0.523 and 0.534. Brunei banks had an average efficiency in 2013 of 0.373 and increased over the years, specifically, in 2014, the average efficiency of Brunei banks was 0.684, in 2015, there was a slight decrease to 0.621 and increased to 0.845 in 2016, reached 0827 in 2017. Cambodian banks have very good performance compared to Vietnam and Brunei in 2013 reached 0.689 and increased to 0.788 in 2014, reaching 0.723 in 2015 and then slightly decreased over 2016 and 2017 with. The results are 0.637 and 0.646 respectively. 
The average Indonesian banks' efficiency in 2013 was 0.751 ranked highest among 9 ASEAN banking systems. in 2015, it was only 0.65 and the results in 2016 and 2017 were 0.651 and 0.670 . Laos banks also had relatively good efficiency during the study period, the average efficiency in 2013 of Lao banks was 0.507, ranking 3rd after Indonesia and Cambodia and maintained the same efficiency level over the years, Specifically, in 2014, Laos banks had an efficiency of 0.557, 2015 reached 0.601, 2016 reached 0.561 and by 2017 was 0.67 .

Table 4. Descriptive statistics of bank efficiency ASEAN 2013 - 2017.

\begin{tabular}{|c|c|c|c|c|c|c|}
\hline & & 2013 & 2014 & 2015 & 2016 & 2017 \\
\hline \multirow{3}{*}{ Vietnam } & Mean & 0.345 & 0.641 & 0.530 & 0.523 & 0.534 \\
\hline & Max & 1.000 & 1.000 & 1.000 & 1.000 & 1.000 \\
\hline & Min & 0.184 & 0.341 & 0.293 & 0.298 & 0.316 \\
\hline \multirow{3}{*}{ Brunei } & Mean & 0.373 & 0.684 & 0.621 & 0.845 & 0.827 \\
\hline & Max & 0.393 & 0.730 & 0.626 & 1.000 & 1.000 \\
\hline & Min & 0.353 & 0.637 & 0.615 & 0.691 & 0.654 \\
\hline \multirow{3}{*}{ Cambodia } & Mean & 0.689 & 0.788 & 0.723 & 0.637 & 0.646 \\
\hline & Max & 1.000 & 1.000 & 1.000 & 1.000 & 1.000 \\
\hline & Min & 0.301 & 0.342 & 0.320 & 0.378 & 0.412 \\
\hline \multirow{3}{*}{ Indonesia } & Mean & 0.751 & 0.724 & 0.650 & 0.651 & 0.670 \\
\hline & $\operatorname{Max}$ & 1.000 & 1.000 & 1.000 & 1.000 & 1.000 \\
\hline & Min & 0.296 & 0.177 & 0.001 & 0.001 & 0.001 \\
\hline \multirow{3}{*}{ Laos } & Mean & 0.507 & 0.557 & 0.601 & 0.561 & 0.631 \\
\hline & Max & 1.000 & 1.000 & 1.000 & 1.000 & 1.000 \\
\hline & Min & 0.010 & 0.017 & 0.009 & 0.003 & 0.023 \\
\hline \multirow{3}{*}{ Malaysia } & Mean & 0.366 & 0.699 & 0.529 & 0.572 & 0.525 \\
\hline & $\operatorname{Max}$ & 0.543 & 0.902 & 0.757 & 0.773 & 0.861 \\
\hline & Min & 0.210 & 0.436 & 0.428 & 0.386 & 0.342 \\
\hline \multirow{3}{*}{ Philippines } & Mean & 0.488 & 0.712 & 0.603 & 0.529 & 0.519 \\
\hline & Max & 1.000 & 1.000 & 0.953 & 1.000 & 1.000 \\
\hline & Min & 0.200 & 0.526 & 0.386 & 0.324 & 0.319 \\
\hline \multirow{3}{*}{ Singapore } & Mean & 0.336 & 0.801 & 0.612 & 0.528 & 0.518 \\
\hline & Max & 0.382 & 1.000 & 0.991 & 0.815 & 0.773 \\
\hline & Min & 0.293 & 0.597 & 0.353 & 0.362 & 0.367 \\
\hline \multirow{3}{*}{ Thailand } & Mean & 0.405 & 0.778 & 0.656 & 0.632 & 0.555 \\
\hline & Max & 1.000 & 1.000 & 1.000 & 1.000 & 0.831 \\
\hline & Min & 0.165 & 0.506 & 0.269 & 0.444 & 0.407 \\
\hline \multicolumn{2}{|l|}{ Mean } & 0.496 & 0.703 & 0.605 & 0.578 & 0.582 \\
\hline \multicolumn{2}{|l|}{ Max } & 1.000 & 1.000 & 1.000 & 1.000 & 1.000 \\
\hline \multicolumn{2}{|l|}{ Min } & 0.010 & 0.017 & 0.001 & 0.001 & 0.001 \\
\hline
\end{tabular}

Malaysia banking system had very low efficiency in 2013 with only 0.366 but improved in the following years, in 2014 the average efficiency of Malaysian banks was 0.699, increasing by $90 \%$ compared to 2013 , effectiveness in 2015 decreased. compared to 2014 but much higher than 2013 and reached 0.529 then maintained at 0.572 and 0.525 in 2016 and 2017. Philippines banks in 2013 had an average efficiency of 0.488 then increased sharply in 2014 to 0.712 and decreased to 0.603 in 2015 to 2016 and 2017 respectively 0.572 and 0.525 . Similarly, Singapore banks also had very low efficiency in 2013 with an average efficiency of 0.336 but increased sharply in 2014 to achieve the highest efficiency of 0.801 among 9 banks in 2014, although

However, over the years, the average efficiency of Singapore banks decreased steadily, in 2015 , it was only 0.612 , a decrease of $23.6 \%$ compared to 2014 and until 2016,2017 , the efficiency level was only 0.525 and 0.518 . Thai commercial banks had good performance, over the years, the efficiency of Thai banks was always maintained in the first group, in 
2013, the average efficiency of Thai banks was 0.405 and increased sharply in 2014. reached 0.778 with an increase of $92 \%$ compared to 2013 , then slightly decreased in 2015 , 2016 with an average efficiency of 0.656 and 0.632 , by 2017 the efficiency of Thai banks was 0.555 , although there was a decrease compared to other last year but still remained among the group of commercial banks with high average efficiency in ASEAN.

Table 5. Ranking the effectiveness (TE) of ASEAN banks over the years.

\begin{tabular}{|c|l|c|l|c|l|c|l|l|l|c|}
\hline \multirow{2}{*}{ Class } & \multicolumn{2}{|c|}{2013} & \multicolumn{2}{c|}{$\mathbf{2 0 1 4}$} & \multicolumn{2}{c|}{$\mathbf{2 0 1 5}$} & \multicolumn{2}{c|}{$\mathbf{2 0 1 6}$} & \multicolumn{2}{c|}{2017} \\
\cline { 2 - 11 } & Nation & TE & Nation & TE & Nation & TE & Nation & TE & Nation & TE \\
\hline 1 & INDO & 0.751 & SING & 0.801 & CAM & 0.723 & BRU & 0.845 & BRU & 0.827 \\
\hline 2 & CAM & 0.689 & CAM & 0.788 & THAI & 0.656 & INDO & 0.651 & INDO & 0.670 \\
\hline 3 & LAO & 0.507 & THAI & 0.778 & INDO & 0.650 & CAM & 0.637 & CAM & 0.646 \\
\hline 4 & PHIL & 0.488 & INDO & 0.724 & BRU & 0.621 & THAI & 0.632 & LAO & 0.631 \\
\hline 5 & THAI & 0.405 & PHIL & 0.712 & SING & 0.612 & MAL & 0.572 & THAI & 0.555 \\
\hline 6 & BRU & 0.373 & MAL & 0.699 & PHIL & 0.603 & LAO & 0.561 & VN & 0.534 \\
\hline 7 & MAL & 0.366 & BRU & 0.684 & LAO & 0.601 & PHIL & 0.529 & MAL & 0.525 \\
\hline 8 & VN & 0.345 & VN & 0.641 & VN & 0.530 & SING & 0.528 & PHIL & 0.519 \\
\hline 9 & SING & 0.336 & LAO & 0.557 & MAL & 0.529 & VN & 0.523 & SING & 0.518 \\
\hline
\end{tabular}

The study results also show that the level of efficiency of banks by each country, from this efficiency level, shows the ranking position of each country through each year as follows: In 2013, the Indonesian commercial banking system was effective. the average is $0.751 \%$, ranking the second is the Cambodian banks with average efficiency of 0.689 , the third is Laos banks with the average efficiency of 0.507 .

In 2013, Singapore banks had the lowest efficiency of 0.336 , Vietnam and Malaysia banks ranked next with the efficiency of 0.345 and 0.366 respectively. In 2014, Singapore banks ranked first with an average efficiency of 0.801, Cambodia and Thailand banks ranked second and third with an average efficiency of 0.788 and 0.778 , the lowest in 2014 were Lao banks. The average efficiency is 0.557 , Vietnamese banks and Brunei are also among the lowest performing banks with average efficiency of 0.641 and 0.684 . In 2015, the top 3 banks had the highest efficiency of medicine on banks of Cambodia, Thailand and Indonesia with average efficiency of $0.723,0.656$ and 0.650 . In 2016, banks of 3 countries, namely Brunei, Indonesia, and Cambodia, had the highest average efficiency with the levels of $0.845,0.651$ and 0.637 respectively, the lowest performing banks of Vietnam including Vietnam, Singapore and Philippines with average results of $0.523,0.528$ and 0.529 .

In 2017, the drug efficiency was most effective in banks of Brunei, Indonesia and Cambodia with average efficiency levels of $0.827,0.670$ and 0.646 respectively, banks of countries such as Singapore, Philippines and Malaysia had lowest performance in 2017 with the performance levels of $0.518,0.519$ and 0.525 (Table 5)

Table 6. Technical efficiency (TE), Pure efficiency (PE) and scale efficiency (SE) of ASEAN banks in the period of $2013-2017$.

\begin{tabular}{|c|l|c|c|c|c|c|c|c|c|c|}
\hline \multicolumn{2}{|c|}{} & VN & Brunei & Cam & Indo & Laos & Malay & Phil & Sing & Thai \\
\hline \multirow{3}{*}{ TE } & Mean & 0.514 & 0.544 & 0.745 & 0.746 & 0.571 & 0.538 & 0.570 & 0.559 & 0.605 \\
\cline { 2 - 12 } & Max & 1.000 & 0.730 & 1.000 & 1.000 & 1.000 & 0.902 & 1.000 & 1.000 & 1.000 \\
\cline { 2 - 12 } & Min & 0.184 & 0.353 & 0.287 & 0.246 & 0.003 & 0.210 & 0.200 & 0.293 & 0.165 \\
\hline \multirow{3}{*}{ PE } & Mean & 0.601 & 0.699 & 0.807 & 0.803 & 0.884 & 0.709 & 0.662 & 0.864 & 0.783 \\
\cline { 2 - 11 } & Max & 1.000 & 0.883 & 1.000 & 1.000 & 1.000 & 1.000 & 1.000 & 1.000 & 1.000 \\
\cline { 2 - 11 } & Min & 0.195 & 0.642 & 0.408 & 0.296 & 0.458 & 0.240 & 0.324 & 0.485 & 0.274 \\
\hline \multirow{3}{*}{ SE } & Mean & 0.861 & 0.776 & 0.916 & 0.931 & 0.664 & 0.770 & 0.860 & 0.659 & 0.776 \\
\cline { 2 - 11 } & Max & 1.000 & 0.974 & 1.000 & 1.000 & 1.000 & 1.000 & 1.000 & 1.000 & 1.000 \\
\cline { 2 - 11 } & Min & 0.452 & 0.541 & 0.582 & 0.613 & 0.003 & 0.438 & 0.465 & 0.293 & 0.416 \\
\hline
\end{tabular}


Table 7. Malmquist average index of 2013 - 2017 of ASEAN banks.

\begin{tabular}{|c|c|c|c|c|c|}
\hline Year & EFFCH & TECHCH & PECH & SECH & TFCH \\
\hline $2013-2014$ & 1.529 & 0.659 & 1.127 & 1.357 & 1.007 \\
\hline $2014-2015$ & 0.814 & 1.183 & 0.876 & 0.928 & 0.962 \\
\hline $2015-2016$ & 0.964 & 1.035 & 1.027 & 0.939 & 0.998 \\
\hline $2016-2017$ & 1.008 & 1.003 & 1.002 & 1.006 & 1.011 \\
\hline Mean & 1.048 & 0.949 & 1.004 & 1.044 & 0.994 \\
\hline
\end{tabular}

The Malmquist index includes indicators that reflect changes in measures of technical efficiency, technological progress, pure efficiency, scale efficiency and aggregate factor productivity. Malquist index greater than 1 indicates an increase in productivity and vice versa, Malquist index less than 1 will indicate a decrease in productivity of a set of commercial banks in the sample in the period of 2013 - 2017.

The Malmquist index is generally estimated for the system of ASEAN commercial banks in the research period. On average in 2013-2017, the total factor-TFP productivity changed to $1,001(>1)$. However, the improvement in technical change is only 0.949 and the total change of factor productivity reaches $0.994<1$. The results show that ASEAN banks should focus on applying technological changes, improving individual productivity to improve operational efficiency (Table 7).

\section{Conclusions}

The process of studying the system of ASEAN banks, with a sample of 130 banks from 9 countries including: Brunei, Cambodia, Indonesia, Laos, Malaysia, Philippines, Singapore, Thailand and Vietnam.

This study uses a non-parametric approach with the input-oriented DEA method, with the inputs being equity; deposits; loans and operating expenses with one output are the total of income, which measures the performance of commercial banks of ASEAN countries in the period of $2013-2017$.

The result shows that the average overall efficiency of ASEAN commercial banks in the study period is $59.2 \%$, this result shows that, with constant output, banks can save up to $40.8 \%$ input during business operation. Thus, the efficiency of ASEAN commercial banks in the period of 2013 - 2017 is relatively low. This may be because the ASEAN commercial banking system has many shortcomings that have not been overcome after the crisis period of 2008-2012.

Among ASEAN countries in the research period, banks in Indonesia, Cambodia and Thailand are among the most effective, the average efficiency of Indonesian banks in the study period is 0.746 , banks Cambodia has an average of 0.745 and Thailand banks have an average of 0.605. Banks in Vietnam, Malaysia and Brunei had the lowest average efficiency during the study period. Specifically, Vietnamese banks have an average efficiency of 0.514 , Malaysia banks have an average efficiency of 0.538 , Brunei banks have an average efficiency of 0.544 .

The estimation results of Malmquist Index of the system of ASEAN commercial banks in the research period show that the total factor productivity changes $1,001(>1)$. However, the improvement in technical change is only 0.949 and the total change of factor productivity reaches $0.994<1$. The results suggest that ASEAN banks should focus on adopting technological changes, improving individual productivity to improve operational efficiency. 


\section{References}

1. E. Park, Ramayandi, ADB Economics Working Paper Series 233 (2010)

2. M.Z. Abd. Karim, ASEAN Economic Bulletin 8(3), 289 (2001)

3. E. Gardener, P. Molyneux, H. Nguyen-Linh, The Service Industries J. 31(16), 2693 (2011)

4. W.P. Wong, Q. Deng, Benchmarking: An International Journal 23(7), 1798 (2016)

5. U.H.W. Astuti, P.M.A. Saputra, Scientific Annals of Economics and Business 66(2), 141 (2019)

6. Abdel Latef Anouze, Expert Systems 27(4), 231 (2010)

7. K. Mlambo, M. Ncube, African Development Review 23(1), 4 (2011)

8. R. Arrawatia, A. Misra, V. Dawar, Intern. J. of Law and Management 57(3), 217 (2015)

9. N. Apergis, M.L. Polemis, Applied Economics 48, 5276 (2016)

10. S.G. Castellanos, G.A. Del Ángel, J.G. Garza-García, Competition and Efficiency in the Mexican Banking Industry - Theory and Empirical Avidence (Palgrave Macmilan, London, 2016)

11. D.V. Dung, The theory of competitive structure of industry with the enhancement of competitiveness of Vietnamese commercial banks today (National University of Economics, Vietnam, 2015)

12. N.T. Canh, L.Q. Minh, N. T. Ngan, Intern. Research J. of Finance and Economics 127, 65 (2014)

13. Charnes et al., European Journal of Operational Research 2(6), 429 (1978)

14. O.V. Zakharchenko et al., Journal of Reviews on Global Economics 8, 859-872 (2019)

15. R.D. Banker, A. Charnes, W.W. Cooper, Management Science 30(9), 1031 (1984)

16. C.A.K. Lovell, Banking efficiency (Oxford University Press, 1993)

17. T. Coelli, D.S.P. Rao, Springer Science Business Media (LLC 2nd Ed, 2005)

18. D. Ushakov, O. Akulich, H. Hajiyev, N. Sakenov, Public Policy and Administration 18(4), 395-342 (2019)

19. Berger, Humphrey, European Journal of Operational Research 98(2), 175 (1997)

20. M. Ismail, Study of efficiency and competitive behaviour of commercial banks in Malaysia (Cardiff Business School, University of Wales, Cardiff, 2005)

21. D. Ushakov, K. Khairiree, T. Podolskaya, Espacios 40(34), 16-22 (2019)

22. B. Casu, C. Girardone, The Manchester School 74(4), 441 (2006)

23. N.V. Hung, Analysis of factors affecting the performance of Vietnam commercial banks. (National University of Economics, Vietnam, 2008)

24. T. Podolskaya, M. Zhuravlev, A. Sidelnikov, EUrASEANs 2(15), 40-49 (2019) 